\title{
A Firm Analysis Level of Supporting Industries in Hanoi City-Vietnam: Application of Resource-based View and Industrial Organization
}

\author{
Nham Phong Tuan \\ School of Business, University of Economics and Business, Vietnam National University \\ E4, 144 Xuan Thuy road, Cau Giay dist, Hanoi, Vietnam \\ E-mail: tuandhtm@gmail.com \\ Nguyen Thi Tuyet Mai (Corresponding author) \\ Graduate School of International Development and Cooperation, Hiroshima University \\ 1-5-1 Kagamiyama, Higashi-Hiroshima 739-8529, Japan \\ Tel: 81-80-3882-9174_E-mail: tuyetmai1985@hiroshima-u.ac.jp
}

Received: November 15, 2011

doi:10.5539/ijbm.v7n5p53
Accepted: December 20, 2011

Published: March 1, 2012

\begin{abstract}
This paper focuses on applying the resource-based view (RBV) of firms and industrial organization (IO) of strategic management field to explain performance in supporting industries in Hanoi - Vietnam. Specifically, we based our research on the integrated framework of RBV and IO and reviewed previous empirical researches before deciding on testing relationships among organizational capabilities, industry effects, competitive advantage and performance. A multivariate analysis of survey responses of 102 firms belonging to supporting industries in Hanoi city - Vietnam indicates that the firm's organizational capabilities contribute to its competitive advantage that in turn, affects its performance and mediates the organizational capabilities-performance relationship, and that industry effects have both direct and indirect impact on competitive advantages. These findings have considerable implications for academics as well as practitioners. Finally, this study also provides directions for future research.
\end{abstract}

Keywords: Capabilities, Competitive advantage, Industrial organization, Performance, Resource-based view, Empirical, Supporting industries

\section{Introduction}

Since Vietnam's economic reform program-officially called the "doi moi"- was launched in 1986, the Vietnamese economy has increasingly developed and has experienced one of the highest growth in the world. One of the driving forces of this development is an increased role of the industrial sector. This sector made a great contribution in creating employment and raising income (Berry, 2002; Rand, Tarp, Dzung, \& Vinh, 2002). Apart from being based on domestic resources, rapid changes in the economic structure have also attracted an increasing flow of foreign investments, particularly in the manufacturing sector. This, in turn, has helped Vietnam implementing its national strategy of industrialization and modernization of the Vietnamese economy and thus promoting higher economic growth. However, under globalization with fiercer competition, both foreign and local firms, especially manufacturing enterprises in the case of Vietnam, need to improve their international competitiveness through good business connections (Ohno, 2007). Given this need, developing supporting industries has long been considered effective and is also suitable for the business strategies of foreign manufacturing enterprises, especially assemblers, in Vietnam.

However, supporting industries in Vietnam have not been fully developed; they are just at the early stages of development. This limits business opportunities for foreign-invested enterprises, specifically assemblers, because it is costly and time-consuming for them to find good local suppliers (Ohno, 2007). In this context, conducting 
studies and proposing practical actions for the development of the supporting industries in Vietnam is essential. Although some researches of macro level have existed in Vietnam, there is still a lack of empirical research about specific matters at firm level, especially underlying researches about relationships among resources, organizational capabilities, industry effects, competitive advantage and performance of firms through applying the process approach of RBV and IO perspective in strategic management perspectives.

RBV is used here in the supporting industry setting, and conversely gaps in RBV are expected to be filled in by this application. RBV is considered as a very popular theoretical perspective to explain competitive advantage and organizational performance (Crook, Ketchen, Combs, \& Todd, 2008; Newbert, 2007), and many strategy scholars have been substantively influenced by the fundamental arguments of the RBV. RBV assumes that a firm possesses or controls a pool of resources and capabilities (Grant, 2002; Newbert, 2008), and that these resources and capabilities that are different among firms create competitive advantages and their performance (Amit \& Schoemaker, 1993; J.B. Barney, 1991; Newbert, 2008). However, relationships among these theoretical constructs such as resources, organizational capabilities, competitive advantage and performance are still controversial among scholars and thus we still have room for future empirical researches.

Moreover, along with RBV for explaining competitive advantage and performance, IO perspective with Porter's framework is also utilized to explain competitive advantage in this study. Porter (1980) proposed that generally action of firms is affected by environmental effect/external forces. So, in order to cope with external forces, firm will try to position itself into a certain position in the market. Testing Porter's view in this study will provide one more evidences for the literature as well as improving comprehensiveness of the study. Although both RBV and IO perspective have different emphases, they are integrated to complement each other in explaining competitive advantage and performance of firms.

Based on the literature review of the theoretical constructs of RBV, IO perspective and their complementary view for explaining performance, considering the need for more empirical evidences for academics and the community of entrepreneurs, especially in the case of Vietnam, and necessary comparison with previous empirical studies, the purpose of this paper is to examine competitive advantage and performance of firms from two complementary view of RBV (only a remaining part of the comprehensive process approach of RBV) and IO perspective. In other words, it focuses on the relationships among organizational capabilities, industry effects, competitive advantage and performance of firms belonging to supporting industries, by answering the second research question of this study that how are the relationships among organizational capabilities, industry effects, competitive advantage and firm performance?.

This paper is organized as follows: the next section briefly reviews literature about the theoretical constructs of RBV and IO perspective, and argues to develop hypotheses. Following that, the third section presents the data and sample as well as variables and their measurement. In the fourth section, analyses and results are reported. The fifth and sixth sections present a discussion of the findings and our limitations as well as directions for future studies, respectively.

\section{Literature Review and Hypothesis Development}

\subsection{Industrial Organization}

It can be said that Porter $(1980 ; 1985)$ made the most influential contribution to the field employing IO economics. Using a structural analysis approach, Porter (1980) outlines an analytical framework that can be used in understanding the structure of an industry. Whereas the concept of industry structure remains relatively unclear in the field of IO economics, Porter's (1980) Five Forces Model, by more clearly specifying the various aspects of an industry structure, provides a useful analytic tool to assess an industry's attractiveness and facilitates competitor analysis. The ability for a firm to gain competitive advantage, according to Porter (1980; 1985), rests mainly on how well it positions and differentiates itself in an industry. The collective effects of the five forces determine the ability of firms in an industry to make profits. To Porter $(1980 ; 1985)$, the five forces embody the rules of competition that determine industry attractiveness, and help determine a competitive strategy to "cope with and, ideally, to change those rules in the firm's favor" (1985: 4). Therefore, as a refinement of the traditional S-C-P paradigm, and also a significant contribution to the field of strategic management, Porter's framework specifies the competitive structure of an industry in a more tangible manner, as well as recognizes (albeit limitedly) the role of firms in formulating appropriate competitive strategy to achieve superior performance. Porter $(1980 ; 1985)$ suggested generic strategies (low cost leadership, differentiation, and focus) that can be used to match particular industry foci and, thereby, build competitive advantage (cited in Hoskisson, Hitt, Wan, \& Yiu, 1999). 
Central to Porter's view of strategy is the notion of activities. For Porter then, strategy is a consistent array or configuration of activities (M.E. Porter, 1991: 102), aiming at creating a specific form of competitive advantage for which there exist two fundamental types: differentiation or low cost. These in turn, together with the scope of operations define the notion of generic strategies. Within this framework, strategy choice is the product of (and response to) a sophisticated understanding of industry structure (Spanos \& Lioukas, 2001). Porter's view can be illustrated by the following Figure 1.

\section{Insert Figure 1 here}

\subsection{Resource-based View}

Over the last two decades, RBV has emerged as one of the most dominant theoretical perspectives in the field of strategic management (Crook, et al., 2008; Newbert, 2007; Priem \& Butler, 2001). The first formalization of RBV is considered to be the empirical paper written by Barney (1991). Based on the works of previous scholars such as: Penrose (1959), Wernerfelt (1984), and others, Barney (1991) suggested that firms possessing valuable, rare resources and capabilities would attain competitive advantage, which would in turn improve their performance.

One of the primary critiques of Barney's (1991) expression of the RBV over time has been its rather static nature (Newbert, 2007). In response to this missing link between resource possession and resource exploitation, Mahoney \& Pandain reminded scholars that 'a firm may achieve rents not because it has better resources, but rather the firm's distinctive competence involves making better use of its resources' (Mahoney \& Pandain, 1992: 365). They continued by suggesting that firms that make the best use of their resources are those that allocate them in such a way that their productivity and/or financial yield are maximized. Similar arguments were put forth by Peteraf and by Henderson \& Cockburn, who argued that to confer a competitive advantage to a given firm its valuable resources must be properly leveraged (Peteraf, 1993) or managed (Henderson \& Cockburn, 1994). Subsequently, there have been a lot of theoretical work that began to emerge regarding the types of processes to which resources must be subjected in order to exploit their latent value, such as core capabilities (Leonard-Barton, 1992), competences (Fiol, 1991; Reed \& DeFillippi, 1990), combinative capabilities (Kogut \& Zander, 1992), transformation-based competencies (Lado, Boyd, \& Wright, 1992), organizational capabilities (Russo \& Fouts, 1997), and capabilities (Amit \& Schoemaker, 1993).

This attention to process led to the emergence of two theoretical approaches within the RBV. The first was Barney's VRIO (Valuable, Rare, Inimitable and Organizational) framework. Barney (1997) argued that in addition to simply possessing valuable, rare, inimitable (which by then included non-substitutable) resources, a firm also needed to be organized in such a manner that it could exploit the full potential of those resources if it was to attain a competitive advantage. He added that the implementation skills that could ensure proper resource exploitation included such organizational components as structure, control systems, and compensation policies (J.B Barney, 1997; J.B Barney \& Mackey, 2005). In short, the organization of a firm was considered to be a firm-level orientation, strategy, or context that encouraged a general and unified approach to the utilization of its resources (Newbert, 2007). The second and radically new theoretical approach more specifically defined the types of processes by which firms could exploit resources. Teece, Pisano \& Shuen (1997: 510) proposed the dynamic capabilities framework 'to explain how combinations of competences and resources can be developed, deployed, and protected'. To do so, they defined a dynamic capability as 'the firm's ability to integrate, build and reconfigure internal and external competences to address rapidly changing environments' (Teece, et al., 1997: 516).

Building on the work of both sets of scholars, Eisenhardt \& Martin later verified that dynamic capabilities 'are the organizational and strategic routines by which firms achieve new resource configurations as markets emerge, collide, split, evolve, and die (Eisenhardt \& Martin, 2000: 1107). These authors contended that the isolated resources are not real value to the firm. Instead, they reaffirmed that their latent value could only be made available to the firm via its idiosyncratic dynamic capabilities. Similar arguments and even more clarified, Grant (2002: 139) attempted to conceptualize a comprehensive framework of relationships among resources, organizational capabilities and competitive advantage (see Figure 2). Grant (2002) suggested that the basic and primary inputs into organizational processes are the individual resources of the firm such as financial capital, physical equipment, intellectual property, reputation, human resources, and so on. Nonetheless, in most cases, the resources are not so productive on their own. In order for the firm to create competitive advantage, individual resources must work together to initially establish organizational capabilities. Hence, it can be interpreted that there is no direct link between the individual resources and competitive advantage or performance. These 
resources should go into processes to create the organizational capabilities needed to influence directly on the competitive advantage.

To explain more detail about Figure 2, it can be said that Grant originally focused on competitive strategy that is formulated from RBV and IO perspective. That is why the strategy was put centrally on the conceptual model, and industry key success factors (IO perspective) affecting to the strategy were also considered. However, whereas the previous section considered IO perspective (dot frame), this section only takes the remaining part of Grant's framework (bold frame), which emphasizes a process based on RBV from resources through organizational capabilities to competitive advantage. In this process, the competitive advantage is expressed as an actual implementation of strategy (see more detail in next sections). In this sense, Grant's model can be regarded as a comprehensive framework about process approach of RBV.

\section{Insert Figure 2 here}

As such, until now, the RBV has come a long way over the past decade and a half. In that long way, since originally formalized by Barney in 1991, there have so far been many researches which focus on different approaches. Newbert (2007) categorized the theoretical approaches utilized by previous empirical studies of RBV into four types: resource heterogeneity, organizing approach, conceptual-level, and dynamic capabilities. The resource heterogeneity approach argues that a specific resource, capability, or core competence that is valuable, rare, inimitable and non-substitutable, when controlled by a firm, will affect its competitive advantage or performance. The organizing approach explains firm-level conditions in which an effective exploitation of resources and capabilities is implemented. Instead of identifying the actual resources that confer an advantage to a firm, scholars utilizing the conceptual-level approach try to investigate if attributes of a resource identified by Barney (1991) such as value, rareness, and inimitability, can effectively explain performance. Finally, the dynamic capabilities approach emphasizes specific resource-level processes influencing on competitive advantage or performance, in which a specific resource interacts with a specific dynamic capability as an independent variable.

According to Newbert (2007), among these four approaches, the resource heterogeneity one is the most widely used. The organizing approach, conceptual-level, and dynamic capabilities approaches are the second, third and fourth most employed, respectively. One of the reasons for that is related to the measurement of variable, in which a specific resource is quantified somehow more easily than capabilities (Newbert, 2007). However, based on a detailed analysis of all approaches, Newbert (2007) finds out that the most widely used approach -resource heterogeneity- is not the one which received the strongest support from empirical tests. It is also concluded that the firm's organizing context and its valuable, rare, inimitable capabilities (dynamic and otherwise) and core competencies may be more important in determining its competitive position rather than its static resources identified mostly by the resource heterogeneity approach. Newbert (2007) also suggests that because research on the organizing, conceptual-level and dynamic capabilities approaches are still few, any of these approaches used in future research will without doubt improve our understanding of relationships among resources, capabilities, competitive advantage and performance in RBV studies.

From Newbert (2007)'s categories and the development process of RBV since its formalization in 1991 by Barney, it can be understood that the resource heterogeneity and the conceptual-level approach are mostly based on Barney's (1991). The organizing approach follows the type of process approach by Barney's VRIO (1997). The dynamic capabilities approach expresses the new theoretical approach of process by Teece, Pisano \& Shuen (1997) and Eisenhardt \& Martin (2000).

By looking Grant (2002)'s comprehensive framework (Figure 2) and Newbert (2007)'s categories, it can be said that Grant (2002)'s framework inherits the insights of the process approach categorized as the dynamic capabilities one by Newbert (2007). However, Grant (2002) developed his framework into a more comprehensive process from resources to organizational capabilities by resource integration process and then from organizational capabilities to competitive advantage by business operation process (see Figure 3 ).

Insert Figure 3 here

In the comprehensive process by Grant (2002) above, the term "organizational capabilities" may have different implication from types of capabilities used in many previous researches. Generally speaking, by reviewing previous empirical studies, it can be said that there are three types of capabilities: the first is understood as specific or individual, the second is processes, and the third is the organizational capabilities. In the first type, capabilities are characterized as skills or expertise of employees, or intangible resources such as reputation or culture (Carmeli \& Tishler, 2004; Hadjimanolis, 2000), which seem to be quite specific or individual. In this 
sense, capabilities are only considered as the basic inputs equivalent to the specific resources or parts of overall resources in Grant (2002: chap. 5)'s definition (Galbreath, 2005; Grant, 2002; Hall, 1987).

On the other hand, in the most recently emerging trend of RBV, scholars have emphasized more on firm's capabilities as processes. Although authors of many researchers used some different terms such as 'combinative capabilities' (Kogut \& Zander 1992), 'capabilities' (Amit \& Schoemaker 1993), 'architectural competence' (Henderson \& Cockburn 1994), and 'dynamic capabilities' (Eisenhardt \& Martin 2000), their definitions of these terms all indicate the firm's processes that use specific resources and integrate them together, reconfigure and release new resources of competitive advantage.

These new resources can be regarded as output of the processes that turn out to be input of new processes (business operation process) toward competitive advantage. We do not hesitate to name the output of the resource integration processes as a third type of capabilities. This third type can be called organizational capabilities that Grant (2002) implies in the comprehensive framework showing the relationships among resource, organizational capabilities and competitive advantage (also see Figure 3). Moreover, in that sense, it can be said that the term 'resource-based capabilities' used in the empirical studies by Chandler \& Hanks (1994), and Wang \& Ang (2004) should be listed in the third type. As a matter of fact, it is not easy to distinguish clearly between these theoretical constructs of the resource integration processes - from using specific resources to releasing organizational capabilities (new resources) - in empirical works, because the distinction often appears to be based both on the ground of logic and intuition. With this in mind, this paper does not focus on the relationships among these theoretical constructs but it considers the direct link between these new resources (so called organizational capabilities) and competitive positions.

Based on the development stream of RBV that focuses increasingly on the process approach and Newbert (2007)'s conclusion about its explaining strength from previous studies, and his suggestion on researching this approach as well, this study emphasizes on the new process direction (dynamic capabilities) by applying the comprehensive framework of Grant (2002). Apart from such an academic reason, this application seems to be the most appropriate for a practical condition of supporting industry in Vietnam. At present, Vietnam's supporting industries are at the early stages of development. The prerequisites for the industries to improve competitiveness are organizational capabilities for cost reduction, quality and delivery (Ohno, 2006).

\subsection{Complementary views among two perspectives and integrated research framework}

It has been recently recognized that IO and RBV complement each other in explaining a firm's performance (Amit \& Schoemaker, 1993; Conner, 1991; Mahoney \& Pandain, 1992; Peteraf, 1993; Spanos \& Lioukas, 2001). In fact, according to Wernerfelt (1984), Porter's framework and the resource-based view constitute the two sides of the same coin. Spanos \& Lioukas (2001) intuitively argued that value creation stems from the fit of internal capabilities to the strategy pursued, and of strategy to competitive environment (cited in Barney, 1992). Moreover, it could be argued that the resource-based approach provides the "Strength-Weaknesses" part of the overall SWOT framework, while industry analysis supplies the "Opportunities-Threats" part (Foss, 1996). In this respect then, the two approaches are complementary simply because they cover different domains of application (Barney, 1991) within the context of SWOT analysis. While the resource-based approach emphasizes that focusing on firm effects is important in developing and combining resources to achieve competitive advantage, industry effects are also critical. Environmental changes "may change the significance of resources to the firm" (Penrose, 1959:79).

In addition, the complementary view of RBV and IO can be seen in Grant's (2002) framework (Figure 2), which formulation of competitive strategy is affected by industry effects (IO perspective) and organizational capabilities (RBV). This, in turn has impact on competitive advantage and then performance. This paper takes the complementary view on basis of Grant's (2002) framework due to its comprehensiveness. However, when analyzing empirically the framework in this study, due to unavailability of measurement of the formulation of competitive strategy, it is assumed to occur implicitly into business operation process from organizational capabilities to competitive advantage. It means that there is no direct impact from organizational capabilities and industry effects on the formulation of competitive strategy, but industry effects moderate relationship between organizational capabilities and competitive advantage.

Competitive advantages are not measured directly in this paper, but it can be seen through actual implementation of competitive strategy. Because Barney (1991) defines that a competitive advantage is generally conceptualized as the implementation of a strategy that facilitates the reduction of costs, the exploitation of market opportunities, and/or neutralization of competitive threats, which can be also observed by cost reduction, quality and innovation. Organizational capability items are factored as three separate scales supportive of competitive 
advantages: cost leadership, quality, and innovation (Chandler \& Hanks, 1994; Wang \& Ang, 2004). Theoretically speaking, these three dimensions (cost reduction, quality and innovation) are major comprehensive strategy options, which are also quite similar to Porter's competitive strategy (cost leadership and differentiation).

The significant academic purposes of this paper are to provide more empirical evidences for the dynamic capabilities approach of RBV and IO perspective and to test the most direct relationship between organizational capabilities recognized theoretically by Grant (2002:139) and competitive advantage and then performance (bold frame of text boxes in Figure 4) as well as to investigate complementary view of RBV and IO perspective in explaining competitive advantage.

\section{Insert Figure 4 here}

\subsection{Organizational Capabilities and Competitive Advantage}

Previous empirical studies of RBV have usually investigated the direct relationship between: (1) specific resources and performance (Miller \& Shamsie, 1996; Ray, Barney, \& Muhanna, 2004), or (2) specific resources and competitive advantage (Berman, Down, \& Hill, 2002; Hatch \& Dyer, 2004). A majority of the tests listed in the resource heterogeneity approach of RBV examine the direct link (1) (Newbert, 2007). In that sense, they assume that competitive advantage and performance have so far been interchangeably treated (Newbert, 2007), since they are based on the definition by Porter (1985:11), which states that competitive advantage is often regarded as performance. However, statistical support of link (1) and (2) is not strong in general, in which link (2) with competitive advantage seems to be stronger than link (1). Moreover, Powell (2001) indicated a unidirectional correlation that competitive advantage leads to improved performance, not conversely, and hence, tests of direct relationship with performance without going through competitive advantage are methodological mistakes. Therefore, among the relationships of organizational capabilities, competitive advantage and performance, a direct relationship between organizational capabilities and competitive advantage likely exists, rather than straightly with performance.

\section{H1: A firm's organizational capabilities have positive impact on its competitive advantage.}

\subsection{Organizational Capabilities, Industry Effects and Competitive Advantage}

As presented above, Porter acknowledges that industry effects play an important role in formulating competitive strategy and then influence competitive advantage of firms. In other words, within Porter's framework, industry occupies either direct and/or indirect in determining the sustainability of strategic positioning and hence of competitive advantage. Grant's (2002) framework (Figure 4) also shows effects of both organizational capabilities and industry effects on strategy formulation which in turn affects competitive advantage. It can be said that direct industry effects show a direct relationship with competitive advantage. Indirect industry effects are related to strategy formulation prior to going to competitive advantage. Empirical studies (Rivard, Raymond, \& Verreault, 2006; Spanos \& Lioukas, 2001) tested both direct and indirect industry effects. These studies indicated that both direct and indirect effects are significant. This paper also investigates both direct and indirect industry effects on competitive advantage. However, due to unavailability of measurement of strategy formulation in this paper, indirect industry effects are examined by a relationship between an interaction of organizational capabilities and industry effects, and competitive advantage. In other words, industry effects moderate the relationship between organizational capabilities and competitive advantage.

The moderating effects can be realized when considering conditions to establish competitive advantage. In order to establish competitive advantage, two conditions must be present: scarcity and relevance of organizational capabilities (Grant, 2002: 139). For scarcity, if a resource or capability is widely available within the industry, then it may be essential to compete, but it will not be a sufficient basis for competitive advantage. Relevance means that a resource or capability must be relevant to the key success factors in the market. In other words, whether an organizational capability can become competitive advantage of firms depends on nature of that capability related to industry effects. Moreover, also according to Grant $(2002,205)$, emerging competitive advantage depends on external sources of change (understood as industry effects) and internal sources of change (operation process of organizational capabilities).

Therefore, from the above arguments, direct and indirect industry effects can be hypothesized for firms in supporting industries in Hanoi city-Vietnam in following sentences:

\section{H 2: Industry effects have a significant impact on competitive advantage of firms.}

H3: Industry effects moderate significantly a relationship between organizational capabilities and competitive advantage. 


\subsection{Competitive Advantage and Performance}

As mentioned above, although the competitive advantage and performance constructs are often used interchangeably (M.E. Porter, 1985), they have real conceptual difference each other (Newbert, 2008; Powell, 2001), and a causal relationship leads the former to the latter. According to Newbert (2008:749),

Whereas a competitive advantage is generally conceptualized as the implementation of a strategy not currently being implemented by other firms that facilitates the reduction of costs, the exploitation of market opportunities, and/or neutralization of competitive threats (J.B. Barney, 1991), performance is generally conceptualized as the rents a firm accrues as a result of the implementation of its strategies (Rumelt, Schendel, \& Teece, 1994).

Apart from the distinction in conceptual perception, some empirical studies also support this notion. Specifically, Barney (1991) - who first formalized the RBV- suggested the presence of this relationship. In line with this kind of research, Newbert (2008); Ray, Barney \& Muhanna (2004); Schroeder, Bates \& Junttila (2002) and many more support for tests on the relationship between competitive advantage and performance. Certainly, the assumption that competitive advantage improves performance should not imply that the latter will be totally determined by the former because a lot of other factors also influence performance. But still, competitive advantage is obviously a significant element for attaining performance.

\section{H4: A firm's competitive advantage is positively related to its performance.}

According to Newbert (2008), who argues on the basis of Barney (1991), and Castanias \& Helfat (2001), a firm must identify and implement resource-based strategies in order to create an economic value. Newbert (2008) also suggests that to produce a product or service with more benefits through its unique features and/or lower cost than its competitors, a firm must exploit a combination of valuable resource and capability (understood as $1^{\text {st }}$ type of capability indicated above) greater than its competitors. It is hypothesized that no matter how processes of resource and capability are, they only indirectly affect performance. In other words, to generate benefits from its resource-capability combination, a firm must first obtain a competitive advantage deriving from their exploitation (Newbert, 2008). Empirical testing supported this hypothesis. For considering the organizational capabilities as output after specific resources and/or capabilities and their processes (Grant, 2002), it is also hypothesized that the competitive advantage resulting from the organizational capabilities determines the performance of a firm.

H5: A firm's competitive advantage will mediate the relationship between the organizational capabilities and its performance.

\section{Methodology}

\subsection{Data and Sample}

This study focuses on area of Hanoi city, where is one of the most developed locations in Vietnam. It is expected that firms in Hanoi city will be sufficiently representative for the supporting industries in Vietnam as a whole. Due to the lack of comprehensive official statistics of firms belonging to the supporting industries (mechanical, electric and electronic), total population of the targeted firms could not be identified exactly. Based on the above definition of supporting industries and thorough consideration of each firm in Hanoi city through the Vietnam Business Directory, which is the largest business directory in Vietnam, total of 250 firms in Hanoi city in supporting industries was obtained from the directory. This directory is regularly updated and can be directly searched by internet. It is also organized by an agency of the Vietnam Chamber of Commerce and Industry (VCCI). It can be said that these 250 firms are more or less total population in the area of Hanoi city. In order to ensure our reliability for respondents and also to encourage participation, this research was implemented under the VCCI name. VCCI is the national organization representing the enterprise community and associations nationwide.

About the methods of gaining data for this research, a survey by questionnaire was conducted during August and September, 2008 in Hanoi city. A structured questionnaire was administered to the directors of the 250 firms, which belong to supporting industries (mechanical, electric and electronic). It was followed by telephone calls to remind participation and return of questionnaires. Prior to the launch of the official questionnaires, a pilot test of the questionnaire was administered to five firms and experts of the fields of this research. Some modifications were made in several question constructs related to the layout of the questionnaire and some theoretical ambiguities.

Out of the 250 questionnaires sent out, 118 were returned. Among the 118, 102 were valid. Thus, 102 firms are the analysis sample for this paper, accounting for 40.8 percent of the true response rate. Among these 102 firms, 
the average number of employees is 294 , and the average firm age is 11 years. There are 51 Limited liability Companies, 31 Joint stock Companies, and 20 the others, in which 85 out of 102 firms are domestic ones, the others (17) are foreign invested firms. Top management on average has about ten-year working experience in the firm, while their management working experience is around seven years. Also, prior to running the current firm, the working experience of top management in a related sector is 11 years on average.

\subsection{Research Variables}

\subsubsection{Organizational capabilities}

In accordance with the above discussion about organizational capabilities, Grant (2002) classifies this construct into two commonly used approaches: a functional analysis and a value chain analysis. In this study, organizational capabilities in value chain analysis are utilized. The value chain analysis separates the activities of the firm into a sequential chain such as: purchasing, engineering, manufacturing, inventory, sales and marketing, distribution and customer support (Grant, 2002). Organizational capability items are factored as three separate scales supportive of competitive advantages: cost leadership, quality, and innovation (Chandler \& Hanks, 1994; Wang \& Ang, 2004). The selection of these three factors is derived from previous studies by Chandler \& Hanks (1994) and Wang \& Ang (2004), and suggestion from the empirical research by Ohno (2006) about key required factors (quality, cost reduction and delivery) for the competitiveness of supporting industries in Vietnam. Moreover, theoretically speaking, these three factors are also major comprehensive strategy options. Although practically it seems to be quite reluctant to mention about the innovation factor because most of the Vietnam's supporting industries are still at their infancy stage, to be objective and comprehensive, the innovation factor should be taken into account.

Each factor (cost reduction, quality and innovation) is considered in the value chain analysis. Specifically, respondents were asked to rate a set of capabilities of cost reduction, quality and innovation in comparison with competitors in the same product lines (five-point Likert scales, $1=$ great disadvantage, $5=$ great advantage). The first capability is measured through sub-scales: low-cost materials, labor, designs to economize on materials, level of capacity utilization, degree of automation, effective sales promotion, and execution. The second capability is perceived through purchased inputs, product engineering skills, strict quality control, identifying and responding to market trends, and quality and effectiveness of customer service. The final one is also observed on purchasing, product engineering, process engineering, and marketing (see more detail in Annex).

\subsubsection{Industry effects}

Zahra (1993)'s construct of environmental dynamism is applied to measure industry effects in this study. Respondents were asked to rate changes in the past three years for four aspects: technology, market, industrial organization, and government regulation for industry. Each aspect is measured by a five-point Likert scale $(1=$ minor change to $5=$ major change). This variable is operationalized by averaging the responses to the four items (see more detail in Annex).

\subsubsection{Competitive advantage}

Barney (1991) defines that a competitive advantage is generally conceptualized as the implementation of a strategy that facilitates the reduction of costs, the exploitation of market opportunities, and/or neutralization of competitive threats (see also Newbert, 2008). Competitive advantages in this study are measured as the implementation of strategies of cost-leadership, quality, and innovation. Constructs of these three strategies are developed based on references from Chandler \& Hanks (1994), Grant (2002: chap. 8\&9), and Wang \& Ang (2004). Specifically, respondents were asked to assess the actual implementation of competitive strategies - cost leadership, quality and innovation- in their firm on a five-point Likert scale $(1=$ strongly disagree to $5=$ strongly agree). Cost strategy is measured through sub-scales: emphasizing on cost reductions via process innovation, in business operation system, investing in machinery, improving productivity and the operations of employees. Quality strategy is reflected by focusing on product quality, strict quality control, meeting customer needs and their requirements about products. Innovation strategy is measured by striving to be the first to introduce new products, stressing production process innovation, and engaging in novel marketing. Similarly to the constructs of capabilities above, all sub-scales for each strategy are pooled into a corresponding single strategy (see more detail in Annex). On the basis of the five-point measure, the higher the rate of each construct, the greater the firm's competitive advantage.

\subsubsection{Firm performance}

This paper uses a subjective financial performance indicator (sales growth) as the only measure. The indicator of sales growth is the most preferred in many empirical studies (Davidsson, Achtenhagen, \& Naldi, 2006; 
Weinzimmer, Nystrom, \& Freeman, 1998). In this study, respondents were asked to evaluate sales growth in five consecutive years on a five-point Likert scale $(1=$ significantly decreased to $5=$ significantly increased $)$. It is believed that this scale will serve as the most appropriate indicator of firm performance.

\subsubsection{Control variables}

As in previous empirical studies (Chandler \& Hanks, 1994; Newbert, 2008; Wang \& Ang, 2004), this study controls some variables, including firm size (total number of employees), firm age (measured from established year up to the year 2007) and legal status (limited liability companies $=1$, the others $=0$ ).

\subsection{Analysis Method}

This paper uses an analysis method of ordered probit regression. This kind of regression is appropriate with the dependent variables measured by ordinal level from one to five with greater frequencies of the middle categories than the high and low tail ones (Garson, 2009). Moreover, a hierarchical regression analysis is also applied to consider changes between control model and full model.

In particular, according to Long \& Freese (2006), the following structural model is used to analyze the data:

$$
y=\beta \mathrm{x}+\varepsilon
$$

where $\mathrm{y}$ is a vector of the dependent variable, ranging from $-\infty$ to $\infty$. $X$ is vector of independent variables, $\beta$ is the parameter to be estimated, and $\varepsilon$ is a random error.

A standard formula for the predicted probability in the ordinal regression model is as follows:

$$
\operatorname{Pr}(y=m \mid x)=F\left(t_{m}-\beta \mathrm{x}\right)-F\left(t_{m-1}-\beta \mathrm{x}\right)
$$

where $m$ is ordinal categories, $t_{m-1}$ and $t_{m}$ are cutpoints, $F$ is the continuous distribution function for $\varepsilon$. In ordinal probit, $F$ is normal with $\operatorname{Var}(\varepsilon)=1$.

Apart from control variable models, this paper estimates below full models:

$$
\begin{aligned}
& \text { Model A: } \operatorname{Pr}(c r a=m \mid x)=F\left(t_{m}-\beta \mathrm{x}\right)-F\left(t_{m-1}-\beta \mathrm{x}\right) \\
& \text { Model B: } \operatorname{Pr}(\mathrm{qa}=m \mid x)=F\left(t_{m}-\beta \mathrm{x}\right)-F\left(t_{m-1}-\beta \mathrm{x}\right) \\
& \text { Model C: } \operatorname{Pr}(i a=m \mid x)=F\left(t_{m}-\beta \mathrm{x}\right)-F\left(t_{m-1}-\beta \mathrm{x}\right) \\
& \text { Model D: } \operatorname{Pr}(a c a=m \mid x)=F\left(t_{m}-\beta \mathrm{x}\right)-F\left(t_{m-1}-\beta \mathrm{x}\right) \\
& \text { Model E: } \operatorname{Pr}(g r s=m \mid x)=F\left(t_{m}-\beta \mathrm{x}\right)-F\left(t_{m-1}-\beta \mathrm{x}\right)
\end{aligned}
$$

where cra is cost reduction advantage; $q a$ is quality advantage; $i a$ is innovation advantage; aca is average competitive advantage and grs is sales growth.

Among these above mentioned full models, Model A, B and $\mathrm{C}$ are for estimating H1, H2 and H3; Model D is just an additional model for testing a relative comparable impact of each capability on average competitive advantage; Model E includes three specific models (Model 2, 3 and 4) in Table 5-3 to completely test $H 4$ and H5.

\section{Analysis and Results}

Table 1 provides descriptive statistics including mean, standard deviations and product moment correlation (Pearson). Correlation coefficients among variables of capabilities and competitive advantages are the most noteworthy (bolded statistics). It can be seen that these coefficients are in a range of 0.54 to 0.81 . This shows that the relationships among these variables are quite strong so this may cause a problem of multicollinearity in subsequent regression analysis. However, by checking the variance inflation factor (VIF) for these variables with the highest coefficient of less than 4, which is still below the VIF of 10 (Kennedy, 1992: 183), it can be said that the subsequent tests are implemented in a reliable way.

\section{Insert Table 1 here}

Table 2 shows the results of the hierarchical ordered probit regression analysis used to test hypothesis $H 1$. There are four hierarchical ordered probit regression models, in which the first three is related to individual competitive advantage as a dependent variable (cost reduction, quality, and innovation) to conclude hypothesis $\mathrm{Hl}$, while the last one is the model of average competitive advantage, which is calculated by averaging the points of three competitive advantages, to provide additional results of a relative comparable impact among capabilities in spite of not being related to test hypothesis $H 1$. Due to applying the hierarchical regression, each dependent variable is regressed against the control variables firstly, and then other main explanatory variables are added to create a full model. By doing that, the full model is compared with the control model to evaluate the explanatory power of the 
additional variables and see if they fit the data. As can be seen from the results in Table 2, the Log Likelihood coefficients indicate that the full models fit the data well and fit much better than the control variables models. The Pseudo $R^{2}$ also indicates that the full models explain a considerable amount of the variance in dependent variable. In comparison with the control variables models, it is the additional variables which contribute the greatest to the amount of the variance.

\section{Insert Table 2 here}

The coefficients of control variables show that firm size is significant and positive in models of cost reduction and quality, but not innovation. However, the other control variables are insignificant in all first three models. These results suggest that these variables have little or no impact on competitive advantage.

For testing hypothesis $H 1$, in model of cost reduction advantage, among the organizational capabilities, the cost reduction capability is only one which has significant and positive impact. The cost reduction and quality capability variables are positive and significant in model of quality advantage. Both the quality capability and innovation capability are positive and significant in innovation advantage model. It can be said that each specific advantage model is explained the best by its respective capability, except for the case of the innovation advantage. In this case, the quality capability has a little stronger influence on innovation advantage than the innovation capability. This finding supports partly hypothesis $H 1$, that a firm's organizational capabilities have significant and positive impact on its competitive advantage, but not all three organizational capabilities have significant impact on each competitive advantage.

Table 2 also reports considerable results on each of the particular capabilities making the strongest impact on its respective advantage. Specifically, the cost reduction capability has the strongest influence on cost reduction advantage, but less on the quality advantage and not on the innovation advantage. Similarly, the quality capability has strongest impact on quality advantage, but not on the cost reduction advantage and less on the innovation advantage. The innovation capability has strongest effect on innovation advantage, but neither on the cost reduction advantage nor the quality advantage.

Without aiming at examining hypothesis $H 1$, the model of average competitive advantage in Table 2 is only to enable to compare a relative impact of each capability on average competitive advantage. The comparison is expected to provide considerable implications for practitioners. As results indicated, all these organizational capabilities show significant positive impact on the average competitive advantage in full model, in which by looking at coefficients of each capability, the explanatory power from the most to the least is quality, cost reduction and innovation capabilities, respectively.

For examining $H 2$, it can be seen from Table 2 that industry effects have no any significant impact on competitive advantages. It also means that direct industry effects on competitive advantage are not realized. Therefore, $H 2$ is rejected.

Table 3 show results of testing $H 3$ that hypothesizes moderating influence of industry effects for relationship between organizational capabilities and competitive advantages. It can be indicated that industry effects moderate relationship between cost reduction capabilities, and cost reduction advantage and quality advantage. They also moderate relationship between innovation capabilities and innovation advantage. However, they do not moderate any relationship between quality capabilities and competitive advantages. Hence, $H 3$ is partly supported.

When considering the findings from Table 2 and Table 3 together, it can be said that out of five direct significant impact of organizational capabilities on competitive advantage, there are three significant moderating influence of industry effects on the relationship between organizational capability and competitive advantage. It can be interpreted that cost reduction capability has both direct impact on cost reduction and quality advantages, and moderated effects by industry forces on these competitive advantages. Innovation capability also has direct influence on innovation advantage and moderated effects by industry forces on the innovation advantage.

\section{Insert Table 3 here}

Hypotheses $H 4$ and $H 5$ are also tested by using the hierarchical regression analysis, in which Model 1 is the control model for all the other Models 2, 3 and 4 (Table 4). In examining these two hypotheses, all three specific competitive advantages become the independent variables. As can be seen from results in Table 4, all $\log$ Likelihood coefficients suggest that the full models (Model 2, 3 and 4) fit the data well, and that the addition of other main variables to these models significantly improves the fit of the data. These results also show that the full models explain a considerable amount of the variance in performance, which in each case reflects a substantial increase from the control variable model. 


\section{Insert Table 4 here}

With respect to testing hypothesis $H 4$, the parameter estimates for the control variables show insignificant impact in Model 2. It can also be seen that the parameter estimates for all of three particular competitive advantages are significant and positive in Model 2, indicating that a firm's these competitive advantages are indeed a very important explanatory variables to its performance, in which the quality advantage and innovation one explain performance the best and the least, respectively. Hence, hypothesis $H 4$ is supported.

In order to consider the mediation of competitive advantage, thus testing hypothesis $H 5$, the following four conditions must be met (Baron \& Kenny, 1986; Newbert, 2008): (1) organizational capabilities must be related to competitive advantage, (2) competitive advantage must be related to performance, (3) organizational capabilities must be related to performance in the absence of competitive advantage, and (4) the effects of organizational capabilities on performance must be reduced or eliminated upon the inclusion of competitive advantage to the model.

Whereas the first condition (1) can be observed in Table 2 and the second condition (2) can be realized from Model 2 of Table 4, the third (3) and fourth (4) condition will be referred to Model 3 and Model 4 of Table 4, respectively. In Model 3, the coefficients of the control variables show that only firm size has significant and positive effect on performance. Among three organizational capabilities, two of them cost reduction and quality capabilities are significantly and positively related to performance. In Model 4, the coefficients of the control variables show that only environmental dynamism has also significant and negative effect on performance. Among the other main variables, two of them cost reduction and quality advantages are significantly and positively related to performance.

When considering Table 2 and Table 4 together, all four conditions are met for the capabilities of cost reduction and quality. Specifically, these two capabilities variables are significantly and positively related to their respective competitive advantages (Table 2) that have significant and positive impact on performance (Table 3 ). Plus, the cost reduction capability and the quality capability also have significant and positive effect on quality advantage and innovation advantage, respectively (Table 2) that are significant related to performance. They are also related to performance without competitive advantage, and their effects on performance are reduced from 0.34 to 0.10 (cost reduction capability) and from 0.54 to 0.37 (quality capability) due to the inclusion of competitive advantage to the model (Table 4). However, unfortunately, the third condition is not satisfied for innovation capability, as the result shows that this variable is insignificant to performance in the absence of competitive advantage. Taken together, these findings suggest that cost reduction advantage mediates the relationship between cost reduction capability and performance; that quality advantage mediates the relationship between cost reduction capability and quality capability, and performance; that innovation advantage mediates the relationship between quality capability and performance; but that all three competitive advantages do not mediate for innovation capability-performance relationship. Thus, hypothesis H5 is partly supported.

\section{Discussion and Conclusion}

This paper has focused on examining the relationships among organizational capabilities, industry effects, competitive advantage and performance in the supporting industries in Hanoi city-Vietnam. Based on reviewing the literature of RBV and IO perspective, five hypotheses were raised to test the above mentioned relationships. They are that the firm's organizational capabilities contribute to its competitive advantage that in turn, affects its performance and mediates the organizational capabilities-performance relationship, and that industry effects have both direct and indirect impact on competitive advantages. As can be seen from the results of our regression analyses that hypotheses $H 1$ is partly supported because not all three organizational capabilities have significant and positive impact on each competitive advantage; that $H 2$ is rejected; that $H 3$ is partly supported because industry effects only moderate three relationships between organizational capabilities and competitive advantages; that $H 4$ are supported; and that hypothesis $H 5$ is only partly supported as all three competitive advantages does not mediate the innovation capability-performance relationship.

These findings may be of interest to both academics and practitioners for several reasons. For academics, by being based on Grant (2002)'s conceptual framework and by examining the dynamic capabilities approach of RBV and IO perspective, this study provides one more evidence to the existing literature about each perspective RBV and IO, and their complementary view for explaining competitive advantage and performance. Firstly, our findings confirm empirically Grant (2002)'s conceptual framework on the relationships among organizational capabilities, industry effects, competitive advantages and performance. It can be said that this is one of the first researches that makes an effort to prove this framework. Moreover, to some extent of logic and observation, this study manages to distinguish the different terms of capabilities used in previous researches, and proposes three 
types of capabilities. By doing that, the organizational capabilities in Grant (2002)'s framework are identified as the third type that is output of resource integration processes.

Secondly, by operationalizing the independent variables in terms of organizational capabilities, and not directly based on individual resources or capabilities, this study reached interesting findings by following the dynamic capabilities approach of RBV. Thirdly, this study presents one more empirical evidence of the conceptual differences between competitive advantage and performance (Newbert, 2008; Powell, 2001). In other words, the analysis showed that it may not be appropriate to test the direct link between resources/capabilities and performance. Lastly, as the findings showed, RBV seems to explain competitive advantage of firms better than IO perspective because H1 (direct impact of organizational capabilities on competitive advantages) is partly supported whereas $\mathrm{H} 2$ (direct effect of industry forces on competitive advantages) is rejected. This finding is almost identical to results of Galbreath \& Galvin (2008). It can be explained by two reasons.

On one hand, RBV followers seem to be more dominant than that of IO perspective in Vietnam's supporting industries. Specifically, Western style, especially American firms tend to put the first consideration on position in industry, and then resource based consideration later. The reason may be that American firms prefer a short term profit. On the contrary, for Japanese firms, resources should come first and then positioning. Japanese firms often follow a long term profit and competitive strategy. This view is also shared with Nobeoka (2010) that compared particularly to American firms, Japanese firms have the temporal leeway to adopt a long-term perspective because they are exposed to less pressure from shareholders for short-term profits. He also contends that the Japanese manufacturers are good at "value creation" in terms of developing and manufacturing products with excellent engineering and manufacturing, but are poor at "value capture" in terms of creating profit and added value (2010: 3 ). Moreover, in the practical context (also explained briefly above), it seems to be true that the reemergence of the internal firm characteristics of RBV was to explain the rising power and global competitiveness of Japanese industry, particularly in 1980s and the success of certain Japanese companies whose competitive advantage could not be explained simply by an industry positioning argument. Japanese industries, especially automobile and electronics at that time are the highly competitive ones and have affected strongly state of industrialization in many Southeast Asian countries. In part as a result of the desire to better understand Japan's approach to business and operations strategy development, RBV gained attention and credibility (Beckman \& Rosenfield, 2007). Furthermore, for supporting industries in Vietnam, quality and cost reduction capabilities are crucial factors for competitiveness at this stage. These capabilities with different accumulations among firms are based on mostly internal firm factors. So, it can be understood that RBV is more suitable than IO perspective to explain competitive advantage and performance.

On the other hand, for IO that focuses externally on industry structure and competitive position in industry, although it may have some effects on supporting industries in Vietnam, these effects seem to be less significant when considering the real condition of the industries. In Vietnam's case, the supporting industries have experienced under the common initial conditions such as local content regulation, taxes and other protective policies from government. Although these protective regulations can be decreased gradually in the coming years due to the 2006 membership of WTO, they can be still in effect to considerable extent until the potential development of the supporting industries in Vietnam has been gained. Under these common conditions, growth and development of firms depend on their internal factors. Therefore, determinants for performance of firms are inherent in the internal firm characteristics, rather than IO.

For practitioners, as hypothesis $H 1$ is partly supported, this finding indicates that the cost reduction, quality and innovation capabilities can make a great impact on their respective competitive advantages of firms belonging to supporting industries. It may lead to the way in which owners/managers make decisions to improve their competitive advantage. It is also consistent with suggestions by Ohno (2006) about key factors such as quality, cost and delivery for competitiveness of supporting industries at their current stage of development. Additionally, as indicated above, among these capabilities, the explanatory power for competitive advantage from the most to the least is quality, cost reduction and innovation capabilities, respectively. Although this finding may not be generalizable to all firms, it may be appropriate for the firms in our sample, the most majority of which are domestic firms. For Vietnamese parts manufacturers, at present, it can be said that the most crucial aspect for competitive advantage is quality capability, especially product quality. Their customers - assemblers will never buy their cheap products if quality is not guaranteed (Ohno, 2006).

Moreover, the quality is always the most important criterion in choosing the suppliers, especially for dominant Japanese assemblers in Vietnam (Mori, 2006). For foreign parts suppliers in Vietnam, the cost seems to be the most crucial factor because their quality guarantee is taken for granted (Ohno, 2006). On the other hand, it also may be true that the innovation capability has the least impact on competitive advantage. The first reason might 
be that at the stage of development of supporting industries in Vietnam, innovation is not considered a priority in comparison with quality and cost reduction. The second reason is likely to stand at feature of the supporting industry itself, where the innovation capability, especially product innovation should come often from assemblers. This reality also explains the partly supported hypothesis $H 5$, in which the innovation capability performance relationship is not mediated by competitive advantage.

As presented in previous section for $H 3$, out of five direct significant impact of organizational capabilities on competitive advantage, there are three significant moderating influence of industry effects on the relationship between organizational capability and competitive advantage. Cost reduction capability has both direct impact on cost reduction and quality advantages, and moderated effects by industry forces on these competitive advantages. Innovation capability also has direct influence on innovation advantage and moderated effects by industry forces on the innovation advantage. However, the relationship between quality capability and competitive advantages are not moderated by industry effects. These findings mean that the more industry effects change, the greater a positive impact of cost reduction capability on cost reduction and quality advantages is. The more industry effects change, the greater a positive influence of innovation capability on innovation advantage is. The positive promotion of industry effects can be explained by the early stage of development of supporting industries where market for the industries and need of good suppliers are expanding. In this stage, participants will be given more favorable opportunities to improve competitive advantages. Moreover, it is easy to understand that industry effects moderate the relationship between cost reduction and innovation capabilities but not quality capability, and competitive advantages. The reason may be that cost reduction and innovation capability are more influenced by external factors (Wang \& Ang, 2004). The findings can lead owner/managers to take industry effects into consideration when attempting to improve competitive advantages.

As reported above, hypothesis $H 4$ is fully supported. In this case, owner/managers can obviously identify that performance is explained by the quality advantage the best, then cost reduction and lastly innovation advantage. Moreover, when hypothesis $\mathrm{H} 4$, that competitive advantages are significantly and positively related to performance, is considered in the context of the results for hypothesis H5, our findings show that organizational capabilities do not need to be directly linked to performance. It seems that in order to gain any performance, a firm must first achieve the competitive advantages that stem from its organizational capabilities. In other words, performance can be only achieved if the firm gets the organizational capabilities such as quality and cost reduction to turn into competitive advantages. Obviously, our sample firms can implement it so that such findings emphasize the significance of organizational capabilities and in turn, give hope and motivation for owners/managers of firms to improve these capabilities.

\section{Limitations and Directions for Future Research}

Although this study may provide several useful contributions, like all other researches, it has some limitations. Due to unavailable secondary data, this study uses self-report data perceived by owners/managers. This method may cause biases. The first one is the theoretical constructs used in this research. Though they are built on the basis of previous studies and actual situation of the new studying environment, they may not capture all insights of these constructs. The second one is that the data depends on the subjective perception of respondents. This may lead to gaps with reality.

Moreover, in terms of analysis methods, it would have been best if this paper had conducted factor analysis before proceeding to the next steps. The factor analysis enables us to check the reliability and validity of measurement constructs. However, based on the result of the pilot survey and the appropriate analysis method of ordered probit regression, it is believed that this study is still secured under the above mentioned limitations.

The last constraint may be the size of the sample and the targeted location of the research. The sample size is relatively small and not distributed equally and sufficiently among specific industries, plus the research only focuses on certain areas of the country. Regarding these, one should be careful before making any generalization from this study.

Ultimately, further studies should be implemented. If any researcher wishes to replicate this study, they should be firstly aware of these limitations. In addition, perhaps, one major question is raised from this study; it is in what mechanism those organizational capabilities can be created. Thus, we would strongly suggest trying to answer this question in further studies. In short, future scholars are encouraged to continue to conduct tests using the approaches of RBV due to the lack of research in this area. In doing so, the scholar community as well as practitioners will have more empirical evidences of the fundamental theory of RBV, and thereby improving our understanding of relationships among organizational capabilities, industry effects, competitive advantages and performance. 


\section{References}

Amit, R., \& Schoemaker, P. J. H. (1993). Strategic assets and organizational rent. Strategic Management Journal, 14(1), 33-46. http://dx.doi.org/10.1002/smj.4250140105

Barney, J. B. (1991). Firm resources and sustained competitive advantage. Journal of Management, 17(1), 99-120. http://dx.doi.org/10.1177/014920639101700108

Barney, J. B. (1997). Gaining and Sustaining Competitive Advantage. Reading, MA: Addison-Wesley.

Barney, J. B., \& Mackey, T. B. (2005). Testing resource-based theory. In D. J. Ketchen \& D. D. Bergh (Eds.), Research Methodology in Strategy and Management (Vol. 2, pp. 1-13). Greenwich, CT: Elsevier. http://dx.doi.org/10.1016/S1479-8387(05)02001-1

Baron, R. M., \& Kenny, D. A. (1986). The moderator-mediator variable distinction in social psychological research: conceptual, strategic, and statistical considerations. Journal of Personality and Social Psychology, 51(6), 1173-1182. http://dx.doi.org/10.1037/0022-3514.51.6.1173

Beckman, S. L., \& Rosenfield, D. B. (2007). Operations Strategy: Competing in the 21st Century. McGraw-Hill/Irwin.

Berman, S. L., Down, J., \& Hill, C. W. L. (2002). Tacit knowledge as a source of competitive advantage in the National Basketball Association. Academy of Management Journal, 45(1), 13-31. http://dx.doi.org/10.2307/3069282

Berry, A. (2002). The role of the small and medium enterprise sector in Latin America and similar developing countries. [Online] Available: http://diplomacy.shu.edu/journal/new/pdf/VolIIINo1/berry.pdf(May 6, 2007)

Carmeli, A., \& Tishler, A. (2004). The relationships between intangible organizational elements and organizational performance. Strategic Management Journal, 25(13), 1257-1278. http://dx.doi.org/10.1002/smj.428

Castanias, R. P., \& Helfat, C. E. (2001). The managerial rents model: theory and empirical analysis. Journal of Management, 27(6), 661-668. http://dx.doi.org/10.1177/014920630102700604

Chandler, G. N., \& Hanks, S. H. (1994). Market attractiveness, resource-based capabilities, venture strategies, and venture performance. Journal of Business Venturing, 9, 331-349. http://dx.doi.org/10.1016/0883-9026(94)90011-6

Conner, K. (1991). An historical comparison of resource- based theory and five school of thought within industrial organization economics: do we have a new theory of the firm? Journal of Management, 17, 121-154. http://dx.doi.org/10.1177/014920639101700109

Crook, T. R., Ketchen, D. J., Combs, J. G., \& Todd, S. Y. (2008). Strategic resources and performance: a meta-analysis. Strategic Management Journal, 29(11), 1141-1154. http://dx.doi.org/10.1002/smj.703

Davidsson, P., Achtenhagen, L., \& Naldi, L. (2006). What do we know about small firm growth? In S. Parker (Ed.), Handbook of Entrepreneurship Research (Vol. 2, pp. 361-398). New York: Springer.

Eisenhardt, K. M., \& Martin, J. A. (2000). Dynamic capabilities: what are they? Strategic Management Journal, Special Issue 21(10-11), 1105-1121.

Fiol, C. M. (1991). Managing culture as a competitive resource: an identity-based view of sustainable competitive advantage. Journal of Management, 17(1), 191-211. http://dx.doi.org/10.1177/014920639101700112

Foss, N. (1996). Research in strategy, economics, and Michael Porter. Journal of Management Studies, 33, 1-24. http://dx.doi.org/10.1111/j.1467-6486.1996.tb00796.x

Galbreath, J. (2005). Which resources matter the most to firm success? An explanatory study of resource-based theory. Technovation, 25(9), 979-987. http://dx.doi.org/10.1016/j.technovation.2004.02.008

Garson, G. D. (2009). Quantitative Research in Public Administrative - Probit and Logit Response Models. Statnotes: Topics in Multivariate Analysis. (July 7th, 2009) [Online] Available: http://faculty.chass.ncsu.edu/garson/PA765/probit.htm

Grant, R. M. (2002). Contemporary Strategy Analysis, (4th ed.). Oxford: Blackwell Publishers Inc.

Hadjimanolis, A. (2000). A resource-based view of innovativeness in small firms. Technology analysis \& Strategic management, 12(2), 263-281. http://dx.doi.org/10.1080/713698465

Hall, B. H. (1987). The Relationship between Firm Size and Firm Growth in the U.S. Manufacturing Sector. 
Journal of Industrial Economics, 35(4), 583-606. http://dx.doi.org/10.2307/2098589

Hatch, N. W., \& Dyer, J. H. (2004). Human capital and learning as a source of sustainable competitive advantage. Strategic Management Journal, 25(12), 1155-1178. http://dx.doi.org/10.1002/smj.421

Henderson, R., \& Cockburn, I. (1994). Measuring competence? Exploring firm effects in pharmaceutical research. Strategic Management Journal, Winter Special Issue(15), 63-84.

Hoskisson, R. E., Hitt, M. A., Wan, W. P., \& Yiu, D. (1999). Theory and research in strategic management: Swings of a pendulum. Journal of Management, 25, 417-456. http://dx.doi.org/10.1177/014920639902500307

Kennedy, P. (1992). A Guide to Econometrics. Cambridge, MA: MIT Press.

Kogut, B., \& Zander, U. (1992). Knowledge of the firm, combinative capabilities, and the replication of technology. Organization Science, 3(3), 383-397. http://dx.doi.org/10.1287/orsc.3.3.383

Lado, A. A., Boyd, N. G., \& Wright, P. (1992). A competencybased model of sustainable competitive advantage: toward a conceptual integration. Journal of Management, 18(1), 77-91. http://dx.doi.org/10.1177/014920639201800106

Leonard-Barton, D. (1992). Core capabilities and core rigidities: a paradox in managing new product development. Strategic Management Journal (Summer Special Issue 13), 111-125.

Long, J. S., \& Freese, J. (2006). Regression models for categorical dependent variables using Stata (2nd ed.). College Station, Texas: Stata Press.

Mahoney, J. T., \& Pandain, J. r. (1992). The resource-based view within the conversation of strategic management. Strategic Management Journal, 13(5), 363-380. http://dx.doi.org/10.1002/smj.4250130505

Miller, D., \& Shamsie, J. (1996). The resource-based view of the firm in two environments: the Hollywood film studios from 1936 to 1965. Academy of Management Journal, 39(3), 519-543. http://dx.doi.org/10.2307/256654

Mori, J. (2006). Designing and managing supporting industry databases. In K. Ohno (Ed.), Building supporting industries in Vietnam (Vol. 1, pp. 65-86). Tokyo: Vietnam development forum.

Newbert, S. L. (2007). Empirical research on the resourcebased view of the firm: an assessment and suggestions for future research. Strategic Management Journal, 28(2), 121-146. http://dx.doi.org/10.1002/smj.573

Newbert, S. L. (2008). Value, rareness, competitive advantage, and performance: a conceptual-level empirical investigation of the resource-based view of the firm. Strategic Management Journal, 29(7), 745-768. http://dx.doi.org/10.1002/smj.686

Nobeoka, K. (2010). Value creation and value capture at manufacturing firms: Importance of non-functional value. (May 3rd, 2010). [Online] Available: http://hdl.handle.net/10086/18482

Ohno, K. (2006). Supporting industries in Vietnam from the perspective of Japanese manufacturing firms. In K. Ohno (Ed.), Building supporting industries in Vietnam (Vol. 1, pp. 1-26). Tokyo: Vietnam development forum.

Ohno, K. (Ed.). (2007). Building supporting in Vietnam (Vol. 1). Tokyo: Vietnam development forum.

Penrose, E. (1959). The Theory of the Growth of the Firm. Oxford: Oxford University Press.

Peteraf, M. A. (1993). The cornerstones of competitive advantage: a resource-based view. Strategic Management Journal, 14(3), 179-191. http://dx.doi.org/10.1002/smj.4250140303

Porter, M. E. (1980). Competitive strategy. New York: The Free Press.

Porter, M. E. (1985). Competitive Advantage. New York: Free Press.

Porter, M. E. (1991). Towards a dynamic theory of strategy. Strategic Management Journal (Winter Special Issue 12), 95-117.

Powell, T. C. (2001). Competitive advantage: logical and philosophical considerations. Strategic Management Journal, 22(9), 875-888. http://dx.doi.org/10.1002/smj.173

Priem, R. L., \& Butler, J. E. (2001). Is the resource-based 'view' a useful perspective for strategic management research? Academy of Management Review, 26(1), 22-40. http://dx.doi.org/10.5465/AMR.2001.4011928

Rand, J., Tarp, F., Dzung, N. H., \& Vinh, D. Q. (2002). Documentation of the Small and Medium Scale Enterprise (SME) Survey in Vietnam for the year 2002 (May 10, 2007) [Online] Available: http://www.econ.ku.dk/rand/images/VNDodumentation02.pdf.

Ray, G., Barney, J. B., \& Muhanna, W. A. (2004). Capabilities, business processes, and competitive advantage: 
choosing the dependent variable in empirical tests of the resource-based view. Strategic Management Journal, 25(1), 23-37. http://dx.doi.org/10.1002/smj.366

Reed, R., \& DeFillippi, R. J. (1990). Causal ambiguity, barriers to imitation, and sustainable competitive advantage. Academy of Management Review, 15(1), 88-102. http://dx.doi.org/10.5465/AMR.1990.4308277

Rivard, S., Raymond, L., \& Verreault, D. (2006). Resource-based view and competitive strategy: An integrated model of the contribution of information technology to firm performance. Strategic Information Systems, 15, 29-50.

Rumelt, R. P., Schendel, D., \& Teece, D. (1994). Fundamental Issues in Strategy. Cambridge, MA.: Harvard University Press.

Russo, M. V., \& Fouts, P. A. (1997). A resource-based perspective on corporate environmental performance and profitability. Academy of Management Journal, 40(3), 534-559. http://dx.doi.org/10.2307/257052

Schroeder, R. G., Bates, K. A., \& Junttila, M. A. (2002). A resource-based view of manufacturing strategy and the relationship to manufacturing performance. Strategic Management Journal, 23(2), 105-117. http://dx.doi.org/10.1002/smj.213

Spanos, Y. E., \& Lioukas, S. (2001). An examination into the causal logic of rent generation: Constrasting Porter's competitive strategy framework and the Resource-bases perspective. Strategic Management Journal, 22, 907-934. http://dx.doi.org/10.1002/smj.174

Teece, D. J., Pisano, G., \& Shuen, A. (1997). Dynamic capabilities and strategic management. Strategic Management Journal, 18(7), 509-533. http://dx.doi.org/10.1002/(SICI)1097-0266(199708)18:7<509::AID-SMJ882>3.0.CO;2-Z

Wang, C. K., \& Ang, B. L. (2004). Determinants of Venture Performance in Singapore. Journal of Small Business Management, 42(4), 347-363. http://dx.doi.org/10.1111/j.1540-627X.2004.00116.x

Weinzimmer, L. G., Nystrom, P. C., \& Freeman, S. J. (1998). Measuring organizational growth: Issues, consequences and guidelines. Journal of Management, 24(2), 235-262. http://dx.doi.org/10.1177/014920639802400205

Wernerfelt, B. (1984). A resource-based view of the firm. Strategic Management Journal, 5(2), 171-180. http://dx.doi.org/10.1002/smj.4250050207

Zahra, S. A. (1993). Environment, corporate entrepreneurship, and financial performance: a taxonomic approach. Journal of Business Venturing, 8(4), 319-340. http://dx.doi.org/10.1016/0883-9026(93)90003-N

Table 1. Descriptive Statistics

\begin{tabular}{|l|r|r|r|l|l|l|l|}
\hline \multicolumn{1}{|c|}{ Variables } & \multicolumn{1}{c|}{ N } & \multicolumn{1}{c|}{ Mean } & \multicolumn{1}{c|}{ SD } & \multicolumn{1}{|c|}{$\mathbf{2}$} & \multicolumn{1}{|c|}{$\mathbf{3}$} & $\mathbf{4}$ \\
\hline 1. $\log ($ firm age) & 102 & 0.86 & 0.38 & & & & \\
\hline 2. Log(firm size) & 102 & 1.97 & 0.63 & $0.59^{* *}$ & & & \\
\hline 3. Legal status & 102 & 0.5 & 0.5 & $-0.35^{* *}$ & $-0.43^{* *}$ & & \\
\hline 4. Industry effects & 102 & 3.65 & 0.64 & 0.15 & 0.02 & -0.1 & \\
\hline 5. Cost reduction capability & 102 & 3.49 & 1.00 & 0.12 & 0.10 & 0.04 & -0.02 \\
\hline 6. Quality capability & 102 & 3.66 & 0.92 & 0.17 & $0.20^{*}$ & 0.08 & -0.002 \\
\hline 7. Innovation capability & 102 & 3.43 & 0.97 & 0.01 & 0.06 & 0.08 & -0.04 \\
\hline 8. Cost reduction advantage & 102 & 3.39 & 0.77 & 0.12 & $0.27^{* *}$ & 0.00 & 0.02 \\
\hline 9. Quality advantage & 102 & 3.57 & 0.87 & 0.13 & $0.23^{* *}$ & 0.05 & 0.04 \\
\hline 10. Innovation advantage & 102 & 3.33 & 0.88 & 0.14 & $0.20^{*}$ & -0.02 & 0.09 \\
\hline 11. Growth in sales & 102 & 3.19 & 1.23 & 0.18 & $0.32^{* *}$ & -0.12 & -0.1 \\
\hline
\end{tabular}

${ }^{*} p<.05 ;{ }^{* *} p<.01$ 
Table 1. (Continued)

\begin{tabular}{|c|c|c|c|c|c|c|}
\hline Variables & 5 & 6 & 7 & 8 & 9 & 10 \\
\hline \multicolumn{7}{|l|}{ 1. $\log ($ firm age $)$} \\
\hline \multicolumn{7}{|l|}{ 2. $\log ($ firm size $)$} \\
\hline \multicolumn{7}{|l|}{ 3. Legal status } \\
\hline \multicolumn{7}{|l|}{ 4. Industry effects } \\
\hline \multicolumn{7}{|l|}{ 5. Cost reduction capability } \\
\hline 6. Quality capability & $0.79^{* *}$ & & & & & \\
\hline 7. Innovation capability & $0.72^{* *}$ & $0.81^{* *}$ & & & & \\
\hline 8. Cost reduction advantage & $0.63^{* * *}$ & $0.6^{* * *}$ & $0.54^{* * *}$ & & & \\
\hline 9. Quality advantage & $0.65^{* *}$ & $0.73^{* *}$ & $0.65^{* *}$ & $0.66^{* *}$ & & \\
\hline 10. Innovation advantage & $0.56^{* *}$ & $0.66^{* *}$ & $0.63^{* * *}$ & $0.61^{* * *}$ & $0.69^{* * *}$ & \\
\hline 11. Growth in sales & $0.64^{* *}$ & $0.69^{* *}$ & $0.6^{* *}$ & $0.71^{* *}$ & $0.72^{* *}$ & $0.62^{* *}$ \\
\hline
\end{tabular}

${ }^{*} p<.05 ;{ }^{* *} p<.01$

Table 2. Determinants for Competitive Advantages

\begin{tabular}{|l|l|l|l|l|l|l|l|l|}
\hline & \multicolumn{2}{|c|}{$\begin{array}{c}\text { Cost reduction } \\
\text { advantage }\end{array}$} & \multicolumn{2}{|c|}{ Quality advantage } & \multicolumn{2}{c|}{$\begin{array}{c}\text { Innovation } \\
\text { advantage }\end{array}$} & $\begin{array}{c}\text { Average } \\
\text { competitive } \\
\text { advantage }\end{array}$ \\
\hline Log (firm age) & -0.04 & -0.20 & 0.03 & -0.10 & 0.04 & -0.04 & 0.02 & -0.13 \\
\hline Log (firm size) & $0.48^{* *}$ & $0.52 * *$ & $0.36 * *$ & $0.36^{*}$ & 0.26 & 0.19 & $0.44 * *$ & $0.45^{* *}$ \\
\hline Legal status & 0.19 & 0.10 & 0.23 & 0.11 & 0.08 & -0.06 & 0.19 & 0.06 \\
\hline Industry effects & & 0.10 & & 0.14 & & 0.19 & & 0.19 \\
\hline Cost reduction capability & & $0.92^{* * *}$ & & $0.41 *$ & & 0.13 & & $0.58^{* *}$ \\
\hline Quality capability & & 0.26 & & $0.84 * * *$ & & $0.57 * *$ & & $0.79 * * *$ \\
\hline Innovation capability & & 0.23 & & 0.35 & & $0.53 * *$ & & $0.54 * *$ \\
\hline Observations & 102 & 102 & 102 & 102 & 102 & 102 & 102 & 102 \\
\hline Log Likelihood & -113.22 & -85.65 & -125.05 & -86.33 & -125.66 & -96.21 & -211.45 & -165.72 \\
\hline Pseudo R-squared & 0.04 & 0.27 & 0.03 & 0.33 & 0.02 & 0.25 & 0.02 & 0.23 \\
\hline
\end{tabular}

${ }^{*} p<.10 ;{ }^{* *} p<.05 ;{ }^{* * *} p<.01$

Standardized coefficients reported

Table 3. Moderating Influence of Industry Effects

\begin{tabular}{|l|l|l|l|l|}
\hline & \multicolumn{1}{|c|}{$\begin{array}{c}\text { Cost } \\
\text { reduction } \\
\text { advantage }\end{array}$} & $\begin{array}{c}\text { Quality } \\
\text { advantage }\end{array}$ & $\begin{array}{c}\text { Innovation } \\
\text { advantage }\end{array}$ & $\begin{array}{c}\text { Average } \\
\text { competitive } \\
\text { advantage }\end{array}$ \\
\hline Log(firm age) & -0.25 & -0.16 & -0.11 & -0.21 \\
\hline Log(firm size) & $0.64 * * *$ & $0.47 * * *$ & $0.32^{*}$ & $0.60^{* * *}$ \\
\hline Legal status & 0.20 & 0.21 & 0.03 & 0.18 \\
\hline Cost reduction capabilities x Industry effects & $0.94 * * *$ & $0.43^{*}$ & 0.16 & $0.60^{* *}$ \\
\hline Quality capabilities x Industry effects & -0.08 & 0.44 & 0.37 & 0.36 \\
\hline Innovation capabilities x Industry effects & 0.24 & 0.31 & $0.54 * *$ & $0.49 *$ \\
\hline Observations & 102 & 102 & 102 & 102 \\
\hline Log Likelihood & -92.53 & -98.07 & -100.96 & -178.42 \\
\hline Pseudo R-squared & 0.21 & 0.24 & 0.21 & 0.17 \\
\hline
\end{tabular}

${ }^{*} p<.10 ;{ }^{* *} p<.05 ;{ }^{* * *} p<.01$

Standardized coefficients reported 
Table 4. Determinants for Performance

\begin{tabular}{|l|l|l|l|l|}
\hline \multirow{2}{*}{} & \multicolumn{4}{|c|}{ Sales growth } \\
\cline { 2 - 5 } & Model 1 & Model 2 & Model 3 & Model 4 \\
\hline Log (firm age) & -0.01 & -0.06 & -0.13 & -0.12 \\
\hline Log (firm size) & $0.30^{* * *}$ & 0.14 & $0.31^{* *}$ & 0.18 \\
\hline Legal status & 0.03 & -0.15 & -0.13 & $-0.19^{*}$ \\
\hline Quality advantage & & $0.61^{* * *}$ & & $0.56^{* * *}$ \\
\hline Innovation advantage & & $0.62^{* * *}$ & & $0.43^{* * *}$ \\
\hline Cost reduction capability & & $0.28^{* *}$ & & 0.17 \\
\hline Quality capability & & & $0.34^{* *}$ & 0.10 \\
\hline Innovation capability & & & $0.54^{* * *}$ & $0.37^{*}$ \\
\hline Observations & & & 0.17 & 0.05 \\
\hline Log Likelihood & 102 & 102 & 102 & 102 \\
\hline Pseudo R-squared & -148.14 & -97.06 & -110.81 & -92.52 \\
\hline
\end{tabular}

${ }^{*} p<.10 ; ;^{* *} p<.05 ;{ }^{* * *} p<.01$

Standardized coefficients reported

External forces/Industrial and market forces

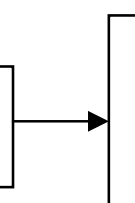

Formulating competitive strategy
Competitive advantage

Figure 1. Porter's view framework

Source: outlined by author

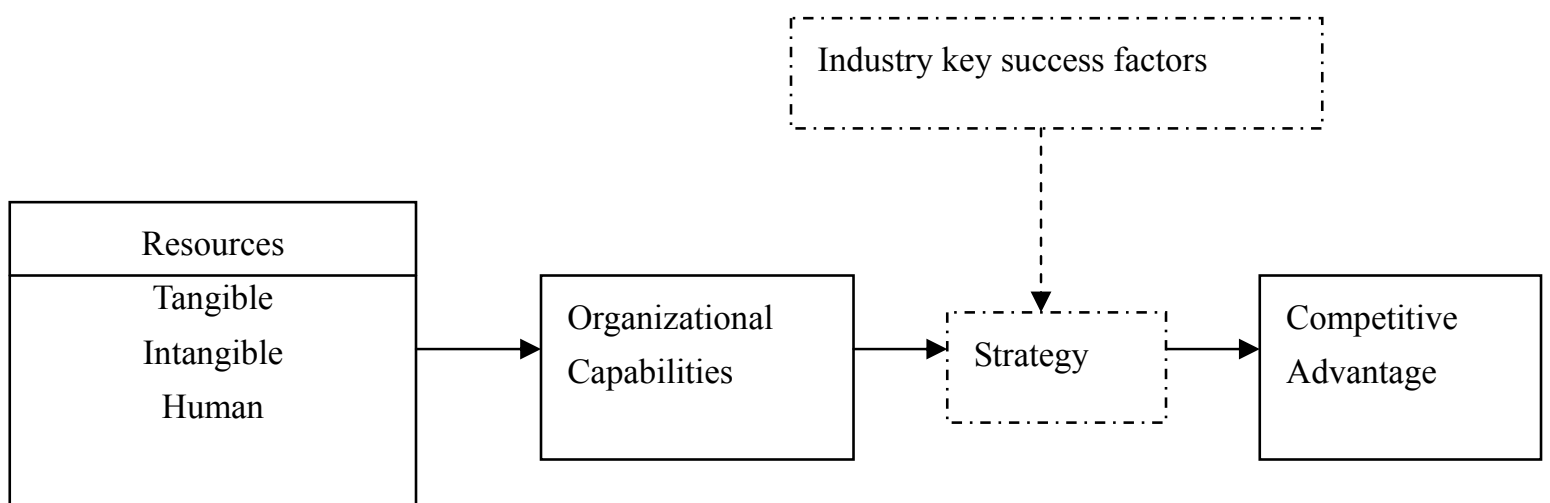

Figure 2. The link among resources, organizational capabilities and competitive advantage

Source: Reproduced by author from Grant (2002: 139) 


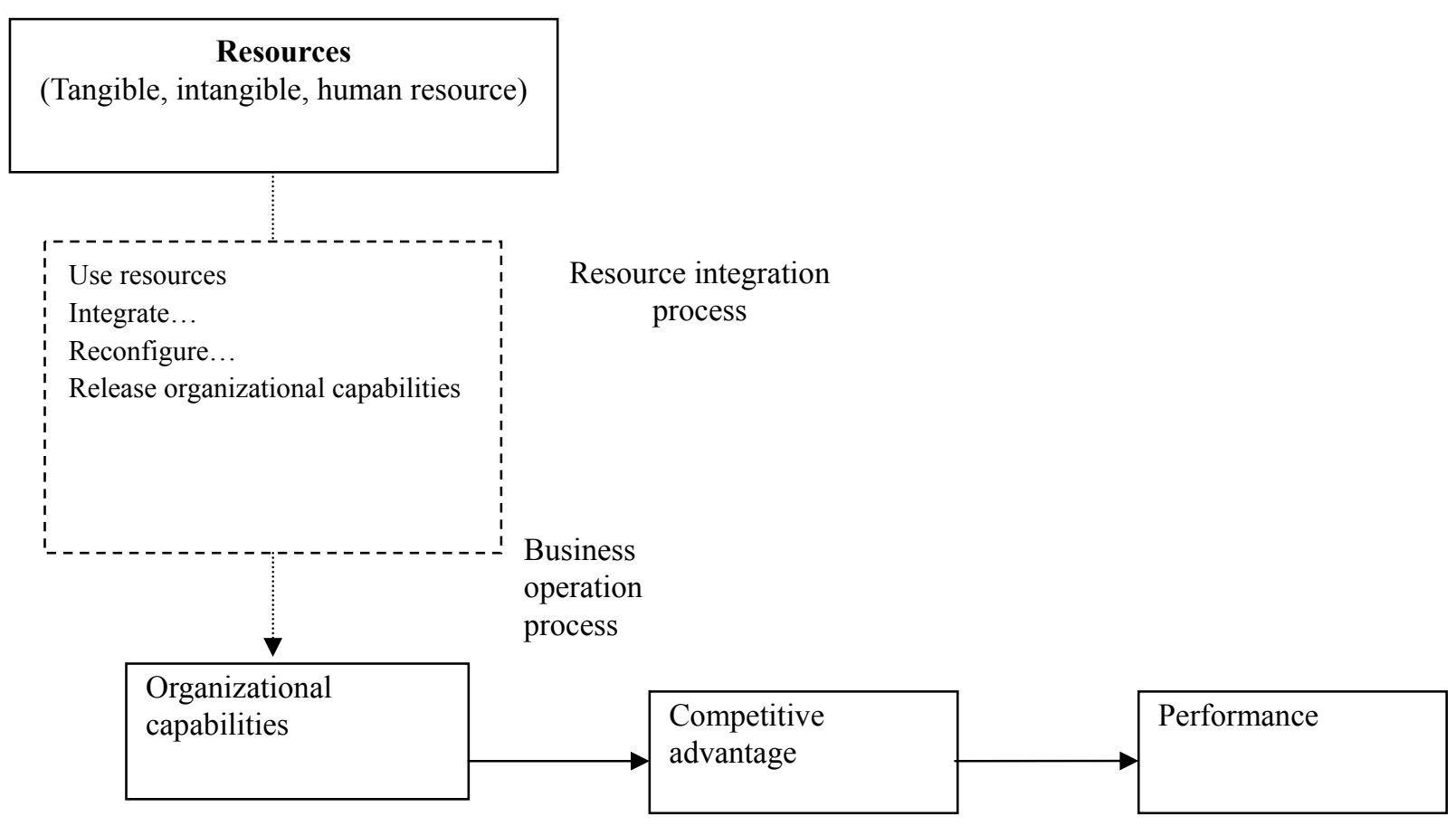

Figure 3. Detailed conceptual description of relationships among resources, organizational capabilities, competitive advantage and performance

Source: Modified by author based on Grant (2002: 139)

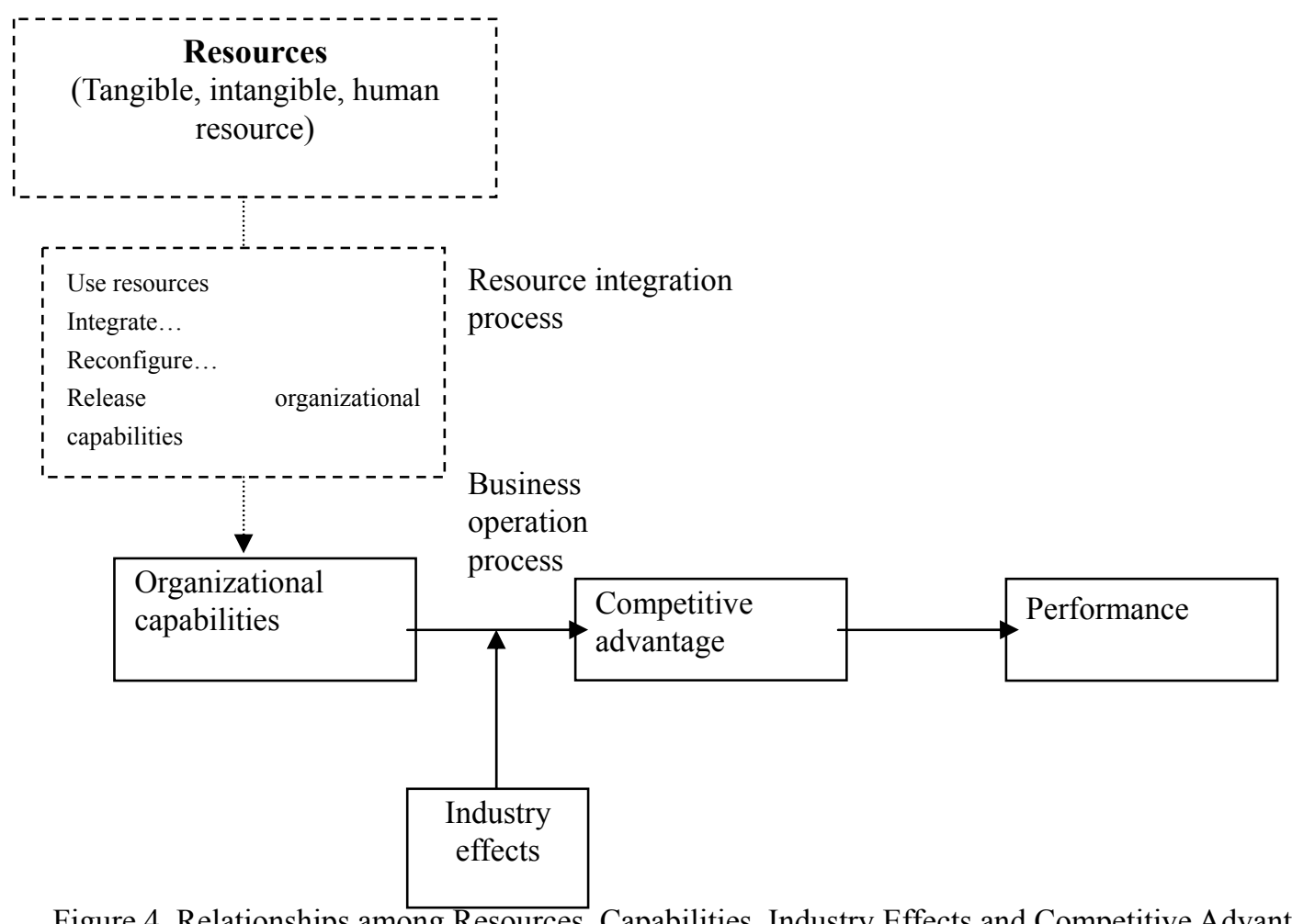

Figure 4. Relationships among Resources, Capabilities, Industry Effects and Competitive Advantage

Source: Modified by Authors Based on Grant (2002: 139) 


\section{Annex - Items in Scales}

I. Organizational Capabilities: rate the capabilities related to the following tasks in your firm in comparison with competitors in same product lines in the last three years.

\begin{tabular}{|c|c|c|c|c|}
\hline $\begin{array}{c}\text { great } \\
\text { disadvantage }\end{array}$ & Slight disadvantage & $\begin{array}{l}\text { Neither advantage } \\
\text { nor disadvantage }\end{array}$ & Slight advantage & great advantage \\
\hline 1 & 2 & 3 & 4 & 5 \\
\hline
\end{tabular}

\section{Capabilities}

Cost reduction (through low-cost materials, labor, designs to economize on materials, level of capacity utilization, degree of automation, effective sales promotion and execution)

Quality (through purchased inputs, product engineering skills, strict quality control, identifying and responding to market trends, quality and effectiveness of customer service)

Innovation (purchasing innovation, product engineering, process engineering, marketing)

$\begin{array}{lllll}1 & 2 & 3 & 4 & 5 \\ 1 & 2 & 3 & 4 & 5\end{array}$

II. Competitive Advantages: rate the actual implementation of Competitive Strategies in your firm.

$\begin{array}{ccccc}\text { Strongly disagree } & \text { Disagree } & \text { Neither agree nor disagree } & \text { Agree } & \text { Strongly agree }\end{array}$

\section{Competitive strategies}

Cost strategy (through emphasizing on cost reductions via process innovation, in business operation system, investing in machinery, improving productivity and operations of employee $\begin{array}{lllll}1 & 2 & 3 & 4 & 5\end{array}$

Quality Strategy (through focusing on product quality, strict quality control, meeting customer needs and their requirements about products)

Innovation strategy (through striving to be the first to introduce new products, stressing production process innovation, and engaging in novel marketing.

III. Environment: rate Environmental Dynamism in the last three years.

$$
\text { minor change }
$$

1

\section{Average change}

3

\section{Relative major change}

4 major change

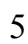

\section{Environmental Dynamism}

Production and product development Technology

Market (Consumer demographics and demand)

Industrial organization (competitors' size and country origin)

Government regulation for industry 